\title{
Implementation of Professional Learning Communities (PLCs) (Differences Between Saudi Arabia and the USA)
}

Jo Nell Wood*

Abdulmajeed K. Alshammari**

\begin{abstract}
Professional Learning Community (PLC) for teachers is one of the trending ways on improving students' achievement. This article aims at investigating the implementation level of Professional Learning Community (PLC) in the schools of United States of America and Saudi Arabia, as perceived by teachers. Also, the article evaluates whether there are significant differences on the implementation level based on country, gender, and years of experience. Participants of the study were public school teachers from both countries. To attain the purpose of the study, the descriptive approach was used. Using Means and Standard Deviation (SD), the findings reveal that the level of implementation of PLC in Saudi Arabia was higher compared to the USA. However, by using T-test and ANOVA, it was revealed that there were no statistically significant differences in the implementation level based on country, gender, and years of experience. Recommendations and suggestions were provided for implementation improvement and future studies.
\end{abstract}

Key words: Professional Learning Community (PLC), teachers' professional development, school improvement

\section{Introduction}

Teachers' professional development is a major part of students' success. Professional learning for teachers emphasized as a crucial part of students' learning (Hord, 2009). One of the most important types of professional learning is Professional Learning Community (Vescio, Ross, \& Adams, 2008), which is seen as a way to engage teachers in improving student achievement. While the United States has been emphasizing the use of PLCs for over two decades, the utilization of PLCs in Saudi Arabia is a newer way for teachers to interact and collaborate about data focused on student achievement (Alshammari, 2017). The ministry of education of the KSA first introduced PLC in 2013 (King Abdullah Project, 2013). Implementing PLCs at schools need to be followed by evaluation to make a better intervention and support.

PLC is defined as "a professional community of learners, in which the teachers in a school and its administrators continuously seek and share learning, and act on their learning" (Hord, 1997, p.1). Little (2012) emphasized that the goal of PLC is to improve teaching abilities and skills in order to support their students' achievement. She confirmed that "we know more about the characteristics of high-quality formal professional development (typically outside the school) than we do about the content,

\footnotetext{
* Dr. Leadership Department, Saint Louis University, USA

** Dr. Hafar Albatin School Disitrict, Ministry of Education, KSA

Corresponding Email: majeed.altarefe@gmail.com
} 
processes, and outcomes of ongoing, informal workplace learning" (Little, 2006, pp. 1-2). Without evaluating the current situation, policy makers and school leaders cannot make appropriate interventions.

East (2015) investigated teachers' perception and found that there is a significant relationship between the level of implementation of PLC and the level of their effectiveness. She found that teachers believed that PLC is an important factor of their students' improvement. There are plenty of studies that found a positive relationship between PLC implementation and effectiveness (Almanzar, 2014; Hord \& Sommer, 2008; Hannaford, 2010). However, Johnson (2011) found no significance in the effect of PLCs on teachers' perception. He argued that timing of implementation might affect the level of implementation. Therefore, researchers need to focus more on the implementation of PLC to help educators and professional development leaders improve their practices using PLC. This study utilized a survey to investigate the implementation level of PLCs and determine differences between implementation and utilization of PLCs by teachers both in Saudi Arabia and in the United States.

\subsection{Research Questions}

This research attempted to answer the following research questions:

1. What are the perceptions of the USA and the KSA teachers on the implementation level of PLC practices on their schools?

2. Are there any significant differences in the implementation level of PLC as perceived by teachers based on their country, gender, and years of experience?

\section{Literature review}

\subsection{Definitions of PLC}

There are plenty of definitions for PLCs, but the core meaning of the term is improving students' outcomes by developing teachers' performance. According to Reichstetter (2006), a PLC is:

made up of team members who regularly collaborate toward continued improvement in meeting learner needs through a shared curricular-focused vision. Facilitating this effort are supportive leadership and structural conditions, collective challenging, questioning, and reflecting on team-designed lessons and instructional practices/experiences, and team decisions on essential learning outcomes and intervention/ enrichment activities based on results of common formative student assessments (p. 1).

The concept of a PLC at its core rests on the premise of improving student learning by improving teaching practice. Another definition offered by Stoll, Bolam, McMahon, Wallace and Thomas (2006) suggested it is a "group of people sharing and critically interrogating their practice in an ongoing, reflective, collaborative, inclusive, learning-oriented, growth-promoting way" (p. 223). The concept of PLC is not new and it has appeared in many sources. Stoll et al. argued that "it is connected with notions of enquiry, reflection and self-evaluating schools. Certain key features were evident in the work of education writers in the early part of the last century" (p. 223). Furthermore, the term was applied by those working within the profession and those supporting schools. Most references to 'learning community' are related to learning through community service, ICT, HE and other community learning. 'Professional community', by contrast, is a body of research starting in the 1980s, largely concerned with schools and departments as mediating contexts for teaching. At the heart of the concept, however, is the notion of community. The focus is not just on individual teachers' professional learning, but on professional learning within a community context - a community of 
learners, and the notion of collective learning. The community focus emphasizes mutually supportive relationships and developing shared norms and values, whereas the focus on professionals and professionalism is towards the acquisition of knowledge and skills, orientation towards clients and professional autonomy (Stoll et al., 2006, p. 225).

\subsection{Characteristics of PLCs}

According to Hord (2004), PLCs have the following characteristics: supportive and shared leadership, shared values and vision, collective learning and the application of that learning, shared practice, and supportive conditions for the maintenance of the learning community. Stoll et al. (2006) confirm these characteristics of PLCs in a recent review of the literature and identify three other characteristics as significant: mutual trust, inclusive school-wide membership, and networks and partnerships that look beyond the school for sources of learning. Little (1993), Kruse, Louis, and Bryk (1995), as well as Darling-Hammond and McLaughlin (2001) added a reflective dialogue, de-privatization of practice, professional growth and mutual support and mutual obligation as other important themes for developing PLCs focused on school improvement.

For the past 25 years, PLCs have been a topic for many researchers and educators in the United States. Professional organizations such as Learning Forward (2011) and the National Staff Development Council (NSDC) have supported the concept of PLCs and added them as a strategy to their common core standards. Learning Forward's Standard on PLC states concerning learning communities: "Professional learning that increases educator effectiveness and results for all students occurs within learning communities committed to continuous improvement, collective responsibility, and goal alignment." Similarly, NSDC's Standard on PLC states, "Learning Communities: Staff development that improves the learning of all students organizes adults into learning communities whose goals are aligned with those of the school and district."

Commissioned by the NSDC, Darling-Hammond, Chung Wei, Andree, Richardson, and Orphanos (2009) compiled a report on teacher development in the United States and abroad. In the preface by Stephanie Hirsh, assistant director at NSDC, to the report entitled "Creating effective professional learning systems to bolster teaching quality and student achievement", the importance of PLCs is stressed by pointing out that collaboration of teachers in a PLC has significant advantages over time. This is because the involved teachers would be able to discuss and reflect on the content they teach in order to improve their skills and knowledge. In a PLC, veteran teachers would mentor and coach novice teachers so they too could become leaders. The purpose of a PLC is to give teachers a chance to meet regularly according to grade-level or content-area. Each PLC adheres to:

a cycle of continuous improvement that begins with examining student data to determine the areas of greatest student need, pinpointing areas where additional educator learning is necessary, identifying and creating learning experiences to address these adult needs, developing powerful lessons and assessments, applying new strategies in the classroom, refining new learning into more powerful lessons and assessments, reflecting on the impact on student learning, and repeating the cycle with new goals (p. 3)

In a model of professional learning communities (PLC), teachers come together to share ideas on instructional practices and try opportunities to examine, learn and reflect on their teaching (Darling-Hammond \& Richardson, 2009). Moreover, this collegiality allows teachers to share what they have to improve their instruction and build up on their expertise. One of the many definitions of PLCs highlights the collegial efforts of teachers working within a group to combine unified knowledge to improve instructional practices and promote student learning (Stoll \& Louis, 2007). Other researchers define it "as a school's professional staff who continuously seek to find answers through inquiry and then act on their learning to improve student learning" (Hipp \& 
Huffman, 2010, p. 11). This collective expertise is utilized by teachers working in groups to influence the curriculum, teaching and learning (Katz, Earl, \& Ben Jaafar, 2009).

\section{Methods}

\subsection{Design}

The researchers used a descriptive approach to attain the purpose of the study. A descriptive survey study was chosen as it assists researchers to gather and examine quantitative data about the sample's characteristics, behaviors, and thoughts (Leedy \& Ormrod, 2016). In their study, teachers' thoughts about their application of PLC were investigated. Leedy and Ormrod (2016) emphasized that a descriptive survey research benefits the researcher "acquiring information about one or more groups of people - perhaps about their characteristics, opinions, attitudes, or previous experiences - by asking them questions and tabulating their answers" (p.141). In this study, the descriptive approach helped the researchers to gather data about the sample's perception, behavior, and characteristics.

\subsection{The Study Sample}

The population of this study was composed of teachers in public schools from Missouri State in the USA and Halil School District in the KSA. The questionnaire was distributed to randomly selected teachers from Hail School District, Saudi Arabia. The number of the respondents was $158.62 \%$ of the participants were female, and $38 \%$ were male. Nearly twenty six percent of the participants from KSA had six to ten years of experience, and twenty-one had one to five years of experience. The same questionnaire was distributed to teachers from the state of Missouri, United States. The number of the respondents were $69.10 .1 \%$ of the participants were female, and $89.9 \%$ were male. The majority of the participants were experiencing their eleventh to fifteenth years of teaching. The total number of the responses from both countries was 227. The information concerning the participants' years of experience is shown in Table1.

Table 1: Participants' Sampling Distribution According to Demographic Variables

\begin{tabular}{|c|c|c|c|c|c|}
\hline & & Saudi Arab & & USA & \\
\hline & & Frequency & Percent & Frequency & Percent \\
\hline & Female & 98 & 62.0 & 7 & 10.1 \\
\hline Gender & Male & 60 & 38.0 & 62 & 89.9 \\
\hline & Total & 158 & 100.0 & 69 & 100.0 \\
\hline & 1-5 Year & 34 & 21.5 & 3 & 4.3 \\
\hline & 6-10 Year & 42 & 26.6 & 2 & 2.9 \\
\hline Years of teaching & 11-15 Year & 6 & 3.8 & 13 & 18.8 \\
\hline & $16+$ Year & 76 & 48.1 & 51 & 73.9 \\
\hline & Total & 158 & 100.0 & 69 & 100.0 \\
\hline
\end{tabular}




\begin{tabular}{|c|c|c|c|c|c|}
\hline \multirow{3}{*}{$\begin{array}{l}\text { Do you believe you have } \\
\text { been engaged in } \\
\text { professional learning } \\
\text { activities during the past } \\
\text { year? }\end{array}$} & Yes & 86 & 54.4 & 49 & 71.0 \\
\hline & No & 72 & 45.6 & 20 & 29.0 \\
\hline & Total & 158 & 100.0 & 69 & 100.0 \\
\hline
\end{tabular}

\subsection{Instrument}

The researchers developed a questionnaire to collect the study data regarding PLC application in the two countries, United States of America and Saudi Arabia. The questionnaire was designed based on the related literature about the PLC best practices. It consisted of two parts. In the first part, the demographic information of the participant (country, gender, and years of teaching experience). The second part contained 37 primary phrases. The respondents were asked to choose their answers from Always, Frequently, Occasionally, Rarely, Very Rarely, and Never on a Likert scale.

The reliability of the instrument of the study was measured using Cronbach's Alpha. The researchers used Cronbach's Alpha coefficients to ensure the internal consistency reliability of the questionnaire. The Cronbach's Alpha coefficient was measured for all the two questionnaires (Table2). The Cronbach's Alpha of the reliability scores of the Questionnaire were (0.96) for the Arabic Questionnaire, and (0.98) for the United States' questionnaire. It is an indicator that the stability of the two questionnaires is high.

Table 2: The Stability of the Instrument (Cronbach's alpha) for the two questionnaires

\begin{tabular}{|l|l|}
\hline Questionnaires & Cronbach's alpha \\
\hline Questionnaire for Saudi Arabia & 0.96 \\
\hline Questionnaire for USA & 0.98 \\
\hline
\end{tabular}

\subsection{Data Analysis}

To answer the first research question "What are the perceptions of the USA and the KSA teachers on the implementation level of PLC practices on their schools?", means and standard deviations (SD) were applied. Also, to identify any significant differences among the study variables (country, gender, and years of experience), T-test for independent-sample and one-way analysis of variance (ANOVA) were implemented.

\subsection{Results}

Answers to the study questions are presented accordingly in this section:

QR1: What are the perceptions of the USA and the KSA teachers on the implementation level of PLC practices on their schools?

As Table 3 shows, the mean scores of Saudi Arabian Teachers responses ranged between 3.46 and 5.14. The overall mean of Saudi Arabian teachers' perception was 4.34 and the standard deviation was 1.04. This indicated that the level of implementation was high. The highest mean score was for item number (26), which is "Teachers in my building use a variety of formative and summative 
data to evaluate the effectiveness and the results of professional learning activities". The lowest mean score was item number (7) which is "Teachers in my building participate with all professional staff members to discuss, document, and demonstrate how their work aligns with the school and the school goals".

The overall mean of the USA teachers' perception is 4.41 and Standard Deviation of 0.55 . The implementation level was also classified as high. The mean score of all items ranged between (3.04-5.26). The highest mean score was for item number (15), which is "Teachers in my building serve as a lead teacher or as a mentor to junior teachers". The lowest mean score was for item number (6), which is "Teachers in my building observe each other teaching a similar or the same lesson and they provide feedback".

Table 3: The Overall Means and Standard Deviations of the Participants' Responses about their Implementation Level of PLC

\begin{tabular}{|c|c|c|c|c|c|c|}
\hline & \multicolumn{3}{|c|}{ Saudi Arabia } & \multicolumn{3}{|l|}{ USA } \\
\hline & Mean* & $\begin{array}{l}\text { Standard } \\
\text { Deviation }\end{array}$ & $\begin{array}{l}\text { Level of } \\
\text { Implementation }\end{array}$ & Mean* & $\begin{array}{l}\text { Standard } \\
\text { Deviation }\end{array}$ & $\begin{array}{l}\text { Level of } \\
\text { Implementation }\end{array}$ \\
\hline Overall & 4.34 & 1.04 & High & 4.41 & 0.55 & High \\
\hline
\end{tabular}

* the means out of 6 .

RQ2: Are there any significant differences in the implementation level of PLC as perceived by teachers based on their country, gender, and years of experience?

First, to determine whether there were any significant differences between teachers' responses due to the country variable a Ttest for independent sample was applied (See Table 4). The T-test analysis revealed no significant differences $(0.63>0.05)$ between the responses of Saudi Arabian teachers and United States teachers regarding their application of PLC practices on their schools.

Table 4: Results of the T-test for Independent Sample due to Country Variable

\begin{tabular}{|l|l|l|l|l|}
\hline Country & Mean & $\begin{array}{l}\text { Standard } \\
\text { Deviation }\end{array}$ & $\mathbf{T}$ & Sig. \\
\hline Saudi Arabia & 4.34 & 1.04 & \multirow{2}{*}{0.48} & 0.63 \\
\hline USA & 4.41 & 0.55 & & \\
\hline
\end{tabular}

** Significant at 0.05 or less.

Second, to investigate whether there were significant differences between teachers' responses due to gender differences a T-test for independent sample was applied (see Table 5). The findings of the T-test analysis revealed no significant differences $(0.96>0.05)$ on the application of PLC practices between the male and female respondents in both countries.

Table 5: Results of the T-test for Independent Sample due to Gender Variable 


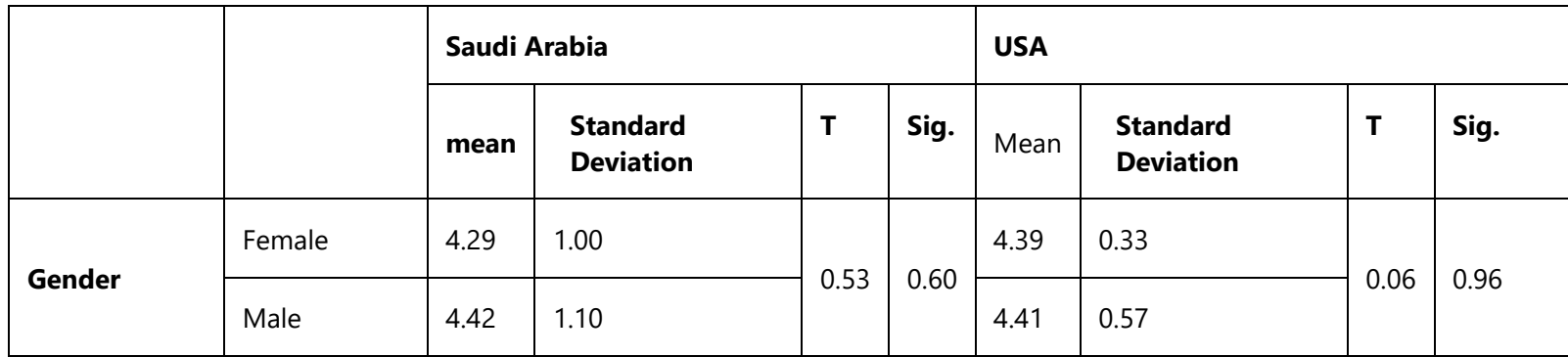

**Significant at 0.05 or less.

Third, to examine whether there were significant differences between the teachers' responses (in the KSA and the USA) due to years of experience variable, the one-way analysis of variance (ANOVA) was applied (see Table 6). The ANOVA is used to investigate the differences between three or more groups. The results of this analysis revealed no significant differences $(0.96>0.05)$ between the answers of teachers from both countries that relate to their years of experience.

Table 6: Differences According to the Participants' Years of Experience (ANOVA)

\begin{tabular}{|c|c|c|c|c|c|c|c|c|c|}
\hline & & Saudi & & & & USA & & & \\
\hline & & Mean & $\begin{array}{l}\text { Standard } \\
\text { Deviation }\end{array}$ & $\mathbf{F}$ & Sig. & Mean & $\begin{array}{l}\text { Standard } \\
\text { Deviation }\end{array}$ & $\mathbf{F}$ & Sig. \\
\hline & 1-5 Year & 4.35 & 0.81 & & & 4.27 & 0.34 & & \\
\hline Years of & 6-10 Year & 4.68 & 0.66 & & & 4.38 & 0.54 & 0.10 & \\
\hline Experience & 11-15 Year & 4.90 & 0.99 & & & 4.37 & 0.59 & & \\
\hline & $16+$ Year & 4.10 & 1.24 & & & 4.42 & 0.56 & & \\
\hline
\end{tabular}

**Significant at 0.05 or less.

\section{Discussion}

While Professional Learning Communities are implemented differently in different contexts (Pang \& Wang, 2018), and "while there may be variations of conceptualization of PLCs and differences of PLC practices in diversified educational contexts, a closer examination reveals in many cases some fundamental similarities" (Brown et al., 2018, p.1). The current study found teacher perceptions concerning implementation of PLCS both in the USA and in Saudi Arabia had a high rating for implementation of PLCs in their counties as shown in Table 3 and there was not significant difference based on gender or years of experience. Both countries' teachers responded that the implementation of PLCs was at a high level. These findings align with the findings of Huffman et al. (2016) who indicated that their findings reinforced the implementation of "school level and district-wide learning communities" (p.28). Further, when considering the PLC as a form of professional development, Al-Mahdy \& Sywelem's (2016) study of Egyptian, Saudi, and Omani schools concluded that Saudi schools did somewhat function as professional learning communities which aligns with the findings in the current study. However, unlike the Al-Mahdy \& Sywelem study which indicated 
that women are more likely to be cooperative and collaborate with others in a PLC model than males, the current study did not find any significant differences between gender participation, although the lowest mean score was given for the statement "teachers in my building observe each other teaching similar or the same lessons and they provide feedback" which could be considered to align to the Al-Mahdy \& Sywelem (2016) indications that males are not as receptive to professional development as females.

In the current study, the responses to the statement "teachers in my building serve as a lead teacher or as a mentor to junior teachers" the mean score was high, just as Al-Mahdy \& Sywelem found in their study as they investigated supportive leadership, collective learning, and supportive relationships. Recently, Admiraal et al. (2019) found that PLC interventions aimed at teacher-leaders, team leaders, and school principals were relatively rare in some Arab schools. And as Huijboom (2020) posited in relation to PLCs in Dutch Schools:

Fostering the development of Professional Learning communities (PLCs) should be a priority for education because of their capacity to enhance teachers' professional development. However, in everyday educational (school) contexts studying and supporting the growth of PLCs is a complex endeavor aimed at teacher-leaders, team leaders and school principals were relatively rare. (p.1)

Although both Egyptian and Dutch Schools rarely see PLCs being implemented with fidelity, the current study has shown that PLCs are becoming more widespread and teachers are more than before engaged in this kind of professional development. It addresses teacher growth and development both in terms of collaboration and knowledge development, which can result in a higher degree of self-efficacy. Professional Development in the form of PLCs can serve as a model for "achieving social change at a larger level if school districts educate their teachers on what constitutes PLCs and what their expectations are as participants in PLCs (Hudson, 2015, p. 66).

\section{Conclusions}

The findings indicate that there is no significant difference between the state of Missouri and Hail District in Saudi Arabia in terms of the level of PLC implementation. The findings indicate that the Ministry of Education in Saudi Arabia has invested in the implementation of PLCs and the teachers are responding positively, as the scores indicate a high level of implementation. Similarly, Missouri Department of Education is providing support for schools to implement PLCs in their schools. Further research should be conducted using a qualitative approach to further probe PLC implementation and determine whether the teachers are using the cycle of continuous improvement. Also, there is a need for evaluating and comparing the effect of PLC in both countries on a larger scale. 


\section{References}

Admiraal, W., Schenke, W., DeJong, L., Emmelot, Y., \& Sligte, H (2019). Schools as professional learning communities: What can schools do to support professional development of their teachers? Professional Development in Education, DOI: 10.1080/19415257.2019.1665573i

Al-Mahdy, Y.F., \& Sywelen, Y.F. (2016). Teachers' perspectives on professional learning communities in some Arab countries. International Journal of Research Studies in Education, 5(4), 45-57.

Almanzar, A. (2014). Impact of Professional Learning Community Practices on Morale of Urban High School Teachers. PhD dissertation. Fort Lauderdale-Davie, FL: Nova Southeastern University. Retrieved 15.-3.2021 from https://files.eric.ed.gov/fulltext/ED545597.pdf

Alshammari, A.K.K. (2017). Teachers and School Principals' Concerns Regarding the Implementation of the Professional Learning Community as an Innovation in Hail School District, Saudi Arabia. Doctoral dissertation. St. Louis, MI: Saint Louis University.

Brown, B. J., Horn, G.S., \& King, G. (2018). The effective implementation of professional learning communities. Alabama Journal of Educational Leadership, 5, 53-59.

Darling-Hammond, L. \& McLaughlin, M.W. (1995). Policies that support professional development in an era of reform. Phi Delta Kappan, 76(8), 597- 604

Darling-Hammond, L. \& Richardson, N. (2009). Teacher learning: What matters? How Teachers Learn, 66(5), 46-53.

Darling-Hammond, L., Chung Wei, R., Andree, A., Richardson, N., \& Orphanos, S. (2009). Professional learning in the learning profession: A status report on teacher development in the United States and abroad. Stanford University: National Staff Development C Council. Retrieved 15.-3.2021 from https://edpolicy.stanford.edu/sites/default/files/publications/professional-learning-learning-profession-status-reportteacher-development-us-and-abroad_0.pdf

East, K.A. (2015). A Study of Professional Learning Communities: Characteristics of Implementation and Perceived Effectiveness in Improvement Schools in West Virginia. Doctoral dissertation. Huntington, WV: Marshall University. Retrieved 15.03.2021 from https://mds.marshall.edu/etd/937

Hannaford, D.B. (2010). A Study of Teacher Perceptions toward a Professional Learning Community in a Rural Middle School. Doctoral dissertation. Minneapolis, MN: Walden University.

Hipp, K.K., \& Huffman, J.B. (2010). Demystifying the concept of professional learning communities. In K. Hipp \& J. Huffman (Eds.), Demystifying professional learning communities: School leadership at its best (pp. 11- 21). New York: Rowman \& Littlefield Publishers.

Hord, S.M. (2009). Professional learning communities. Journal of Staff Development, 30(1), 40-43.

Hord, S. (2004). Learning Together, Leading Together: Changing Schools through Professional Learning Communities. New York: Teachers College Press.

Hord, S. (1997). Professional Learning Communities: Communities of Continuous Inquiry and Improvement. Austin, TX: Southwest Education Development Laboratory. 
Hord, S.M. \& Sommers, W.A. (Eds.). (2008). Leading Professional Learning Communities: Voices from Research and Practice. Thousand Oaks, CA: Corwin Press.

Hudson, Q. (2015). The Effectiveness of Professional Learning Communities as Perceived by Elementary School Teachers. Doctoral dissertation. Minneapolis, MN: Walden University. Retrieved from https://scholarworks.waldenu.edu/cgi/viewcontent.cgi?article=2345\&context=dissertations

Huffman, J.B., Olivier, D.F., Wang, T., Chen, P.Y., Hairon, S., \& Pang, N. (2016). Global conceptualisation of the professional learning community process: Transitioning from country perspectives to international commonalities. International Journal of Leadership in Education: Theory and Practice. DOI:10.1080/13603124.2015.1020343

Huijboom, F., Van Meeuwen, P., Rusman, E. \& Vermeulen, M. (2020). How to enhance teachers' professional learning by stimulating the development of professional learning communities: operationalising a comprehensive PLC concept for assessing its development in everyday educational practice. Professional Development in Education, 46(5) 751-769, DOI: $10.1080 / 19415257.2019 .1634630$

Johnson, D.R. (2011). A Quantitative Study of Teacher Perceptions of Professional Learning Communities' Context, Process, and Content. Doctoral Dissertation. South Orange, NJ: Seton Hall University. Retrieved 15.03.2021 from https://scholarship.shu.edu/cgi/viewcontent.cgi?article=1025\&context=dissertations

Katz, S., Earl, L.M., \& Ben Jaafar, S. (2009). Building and Connecting Learning Communities: The Power of Networks for School Improvement. Thousand Oaks, CA: Corwin Press.

King Abdullah Project Public Education Development Project. (2013). Tatweer school module. Retrieved from: https://www.moe.gov.sa/ar/aboutus/aboutministry/Documents/StrategyArciveGE001.pdf

Kruse, S., Louis, K., \& Bryk, A. (2009). 13 Parameters: A Literacy Leadership Toolkit, Research Resource Book. Thousand Oaks, CA: Pearson.

Leedy, P. \& Ormrod, J. (2016). Practical Research: Planning and Design. Upper Saddle River, NJ: Pearson.

Learning Forward. (2011). Standards for Professional Pearning (4th ed.). Oxford, OH: Learning Forward. Retrieved 15.03.2021 from http://learningforward.org/standards-for-professional-learning\#.Vf3J0t9VhBc

Little, J.W. (2006). Professional community and professional development in the learning-centered school. Teacher Learning that Matters: International Perspectives, 22-46. Washington, DC: National Education Association. Retrieved 15.03.2021 from https://www.researchgate.net/profile/Judith-Warren-

Little/publication/237609303_Professional_Community_and_Professional_Development_in_the_LearningCentered_School/links/568e9bdc08ae78cc0515fa5c/Professional-Community-and-Professional-Development-in-theLearning-Centered-School.pdf

Little, J.W. (1993). Teachers' professional development in a climate of educational reform. Educational Evaluation and Policy Analysis, 15(2), 129- 151.

Pang, N.S. \& Wang, T. (2018). Professional learning communities: research and practices across six educational systems in the Asia-Pacific region. Asian Pacific Journal of Education. 36(2) 193-201.

Reichstetter, R. (2006). Defining a professional learning community: A literature review. E \& R Research Alert, 6(5), 1-4. 
Stoll, L., Bolam, R., McMahon, A., Wallace, M., \& Thomas, S. (2006). Professional learning communities: A review of the literature. Journal of Educational Change, 7, 221-258.

Stoll, L. \& Louis, K.S. (2007). Professional Learning Communities: Divergence, Depth and Dilemmas. London, UK: McGraw-Hill Education.

Vescio, V., Ross, D., \& Adams, A. (2008). A review of research on the impact of professional learning communities on teaching practice and student learning. Teaching and Teacher Education, 24(1), 80-91. 